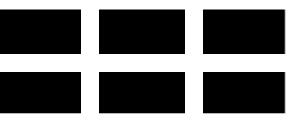

THE WILLIAM DAVIDSON INSTITUTE AT THE UNIVERSITY OF MICHIGAN BUSINESS SCHOOL

\title{
Exchange Rate Regimes and Volatility: Comparison of the Snake and Visegrad
}

\author{
By: Juraj Valachy and Evžen Kočenda
}

William Davidson Institute Working Paper Number 622

October 2003 


\title{
Exchange Rate Regimes and Volatility: \\ Comparison of the Snake and Visegrad
}

\author{
Juraj Valachy $^{*}$ and Evžen Kočenda**
}

CERGE-EI

\begin{abstract}
Exchange rate stability was defined as one of the prerequisites for monetary integration in Europe. In this paper, we analyze recent developments in the volatility of exchange rates of the Central European countries (the Visegrad Group) and a selected group of European Union countries (the Snake) participating in the former European Monetary System. We compare volatilities in the currencies of both groups under specific exchange rate regimes using two different approaches to modeling exchange rate volatility: squared returns parametric model and GARCH. Both methods provide identical results for the currencies of the Visegrad group: an increase in volatility after a floating exchange rate regime was introduced. The case of the Snake countries exhibits mixed results for two currencies and a concurring result for the others: a decrease in volatility. In one case we are left with an insignificant coefficient. We consider the results as robust and suitable for policy making decisions.
\end{abstract}

Keywords: exchange rate regime, volatility, transition, integration, Central Europe, European Union, nonlinearity, interest rate parity

JEL Classification: C14, C22, C51, E43, F31, F33, F36, P59

* Ministry of Finance, Bratislava, Slovak Republic and CERGE-EI. E-mail: juraj.valachy@cergeei.cz,

CERGE-EI (a joint workplace of Charles University and the Academy of Sciences of the Czech Republic) P.O.Box 882, Politických vězňů 7, 11121 Prague, Czech Republic. E-mail: evzen.kocenda@cerge-ei.cz, WDI, and CEPR

We would like to thank Jan Hanousek, Jan Kmenta, Lusio Vinhas de Souza, and participants of the November 2002 ICEG conference on "Exchange Rates" held in Budapest for helpful comments.

Kočenda holds a Citibank professorship at CERGE-EI. While preparing this paper, the authors benefited from GAUK Grant No. 273/2002/A-EK/CERGE. This research was supported by a grant GDN III 034 from the CERGE-EI Foundation under a program of the Global Development Network. All opinions expressed are those of the authors and have not been endorsed by CERGE-EI, WIIW, or the GDN. 


\section{Introduction and Motivation}

This paper analyzes the volatility of the exchange rates of the Central European countries and compares it to the volatility of exchange rates of the European Union countries participating in the former European Monetary System. Since exchange rate stability was defined as one of the prerequisites for monetary integration in Europe, the topic is important for prospective candidates from transition countries. Further, realized volatility under specific exchange rate regimes can be used to compare the prospects of candidate countries for exchange rate policies during the pre-accession period.

A parallel in the development of exchange rate regimes in the European Union and advanced transition countries underlies the motivation to compare exchange rate volatility when an exchange rate regime becomes less tight due to a change in arrangement. The European Monetary System (EMS) was established in March 1979 as a way to stabilize exchange rate volatility within the countries of European Community (EC). According to the EMS, the EC countries agreed to limit fluctuations to their bilateral exchange rates in an obligatory way by interventions of national central banks that was known as the Exchange Rate Mechanism (ERM). From the beginning, all EC countries were members of the EMS but only eight of them initially participated in the ERM: Belgium, the Netherlands, Luxembourg, Denmark, France, Germany, Ireland, and Italy. Spain joined the ERM in 1989 followed by the United Kingdom and Portugal in 1990 and 1992, respectively. Only Greece did not join the ERM. However, after a major exchange rate crisis in September 1992, the United Kingdom and Italy stopped participating. After another crisis in August 1993, the ERM was redefined to allow for wider fluctuation bands.

The European Monetary System was created as a first step towards the full monetary integration of countries participating in this system (originally eleven countries). An essential feature of this system was that all countries adhering to the Exchange Rate Mechanism (ERM) fixed their currencies to all other currencies and then their exchange rates could fluctuate in a range of $\pm 2.25 \%$ from central parity. ${ }^{1}$ The central banks of participating countries were obliged to keep their currencies within the defined band. However, after many attacks and high market pressures (1992-1993), some central banks had to re-align the value of central parity and finally all central banks broadened the fluctuation band to $\pm 15 \%$. Despite the fact that the exchange rate regime was formally still fixed, the width of the band $(30 \%$ in 
absolute value) warrants consideration as a floating regime. Therefore we consider the first part of EMS history dating from March 1979 to 1993 as a period with a fixed exchange rate within a narrow band, and from 1993 to 1999 (the introduction of the Euro) as a period with a floating exchange rate. We hypothesize that the volatility of exchange rates of the EMS member countries during the period of a fixed regime should be different than volatility during the quasi-floating regime from 1993 until 1999. Volatility during the latter period could be used as a proxy to measure exchange rate stability during such a period. Thus, this could be used as a complementary measure of stability stipulated in one of the Maastricht criteria.

In Central Europe the institutional design of exchange rate regimes has varied across countries since the beginning of transition. The degree of exchange rate regime homogeneity is not comparable to that of the former EMS but we can observe certain evolutionary similarities. The exchange rates of the Czech Republic, Poland, Hungary, and Slovakia were fixed from the beginning of the transition process. The Czech and Slovak republics fixed their currencies to a currency basket. Until January 1, 1993 both republics formed a federation and shared a uniform exchange rate policy. Thus, at the beginning of transition, this currency basket consisted of five different currencies, and later of the US dollar and German mark. The weights of each currency in the basket were based on the importance of a particular currency in the foreign trade of the country. The width of the band was set at $\pm 0.5 \%$ from central parity. After the separation in 1993 Slovakia changed the band to $\pm 7 \%$ and later the Czech Republic changed it to $\pm 7.5 \%$. Central banks were obliged to intervene in the currency market to sustain the basket peg. A similar institutional evolution was encountered in Poland and Hungary. The only difference is that these two countries adopted a pre-announced crawling peg to the basket of currencies. The central parity was not constant, as in case of the Czech Republic or Slovakia, but was changed each month. The periodic devaluations were announced ahead of time. In some cases the width of the band was changed during the period as well. The intricacy of such institutional design is clear from Table 1 (for all tables see Appendix B), which displays in extensive detail all the adjustments that the central banks of the four CEE countries adopted in exchange rate management. The abundance of these adjustments is apparent in the cases of Poland and Hungary. ${ }^{2}$

\footnotetext{
${ }^{1}$ A wider band $( \pm 6 \%)$ was provided for Italy during the earlier stage of the system, as well as for Spain and Portugal.

${ }^{2}$ For additional details on regimes in transition countries see Tomczynska (1998).
} 
After the turmoil in financial markets, in May 1997 the Czech Republic was the first Central European country to adopt a floating exchange rate regime. In October 1998, the National Bank of Slovakia followed by adopting this regime as well. Later, Poland (in 2000) and Hungary ("quasi" in 2001) left the fixed regime and also adopted a floating regime. Therefore, we can see a general tendency of easing from a tight exchange regime to a looser exchange regime (Kočenda 2002). Further, the tendency to allow the markets to determine the price of the national currency has been same for both the EMS and Central European countries. The two groups are thus natural candidates for comparison from an exchange regime perspective. Nevertheless, there is another important motivation. All four Central European countries have received an invitation for European Union membership, and already declared a wish to be part of the economic and monetary union (or Euro zone) sooner or later. The membership alone does not mean immediate participation in the Euro zone. However, EU membership will increase pressure to maintain the institutional and economic environment and should even foster the Euro-conversion-oriented development of the exchange rates of Central European countries. A looser exchange regime with the Euro as a reference currency should be considered as a pursuit of a credible peg for a domestic currency with respect to the Euro that allows for necessary responses to the market. As a matter of fact, if a currency fluctuates within a $\pm 15 \%$ band with respect to the Euro, then it implicitly follows the ERM II condition even if the country does not participate formally.

Based on Krugman's (1991) theoretical model, widening the fluctuation band should lead to an increase in the credibility of the band and consequently to lowering the volatility of the exchange rate. Sosvilla-Rivero, Fernandez-Rodriguez and Bajo-Rubio (1999) compare volatility in the six EMS exchange rates before and after the crisis in August 1993. They used an indicator of local volatility based on the inverse of the maximum Lyapunov characteristic exponent as a measure of volatility. They find that broadening the bands would have led, in the first stage, to a decrease in volatility to levels comparable with those prevailing before the crisis. However, the subsequent episode of instability occurring at the end of February and particularly at the beginning of March 1995 witnessed a renewed increase in exchange rate volatility for all currencies considered, the only exception being the Dutch gulden. Similarly, Ayso, Perez-Jurado and Restoy (1994) conclude that broadening of the band led to a decrease in volatility to levels comparable to those prevailing before the crisis. Ledesma-Rodrigues et al. (2003) claim that widening of the fluctuation bands caused an increase in credibility. The higher credibility should reduce the exchange rate sensitivity to a given change in 
fundamentals. An increase in credibility was found for the currencies participating in the ERM, with the exception of the Belgian franc and Irish pound.

Carporale, Hassapis and Pittis (1995) explore how the widening of the EMS band has affected the behavior of excess returns on Deutsche mark denominated assets. Their approach consists of estimating simple forecasting models for interest differentials, and testing for the presence of significant (negative) mean prediction errors. The comparison between predicted and actual outcome indicates that the new system might be characterized by the virtual disappearance of "weak" currencies, as the widening of the bands has removed the expectations of realignments which resulted in high interest differentials.

There is limited number of studies that examine the behavior of the exchange rate under fixed and floating regimes in Central European currencies. Halpern and Wyplosz (1997) document and interpret stylized facts of exchange rates in transition economies. Szapary and Jakab (1998) review the experience of Hungary with the pre-announced crawling band exchange rate system during 1995-97. Ivanicova and Rublikova (2002) analyze the development of the Slovak crown after the introduction of a floating exchange rate regime. Kočenda (1998) compared the volatility of the Czech crown exchange rate when pegged to a currency basket. He found that the volatility of the exchange rate decreased after a much wider fluctuation band was introduced to limit movements of the currency basket index. Brasili and Sitzia (2003) investigate the recent evolution of exchange rates for a panel of Central and Eastern European countries. Kočenda (2002) provides a broader look at the exchange rates and their regimes in Central Europe from the point of view of their convergence depending on different exchange regimes.

A different perspective on EMS behavior is offered by Hallett and Anthony (1997). The authors compare the behavior of EMS currencies with that of non-EMS currencies. They find differences in the third and fourth moments for these two groups of countries which implies that EMS currencies have become more fragile and susceptible to shocks (particularly negative shocks) relative to non-EMS currencies. They warn that the bilateral variances within the EMS may have fallen, but variances against non-EMS countries appear to have risen so that some currencies have become less stable in effective terms. Another possibility is that the EMS had the effect of transferring volatility to another part of the system, and to the real sector in particular.

Evidence of the impact of exchange rate volatility on macroeconomic variables is often mixed. Robertson and Symons (1992) argue that low exchange rate volatility brings greater output growth and lower inflation. Other studies, such as Sapir and Sekkat (1995) or 
Krugman (1989), do not notice the impact of volatility on trade, investment and growth. Flood and Rose (1995) conclude that the fixed exchange rates are less volatile than floating rates, but there is no clear tradeoff between reduced exchange rate volatility and macroeconomic stability. Papazoglou (1999) examines the contribution of exchange rate policy to output growth in the transition economies of Central and Eastern Europe. His analysis indicates that a fixed exchange rate regime during the transition process may serve the growth objective better since, to the extent that it is more effective in reducing inflation, it exerts a positive influence on output growth through the direct channel as well.

Computing the degree of realized volatility is a usual way to assess the evolution and performance of an exchange rate system. We decided to adopt two different ways of computing volatility. The first approach lies in fitting the parametric model with a drift and diffusion function derived from the interest rate parity condition. Then, for the purpose of comparison we use estimates of the diffusion function. The second approach lies in fitting the type of GARCH process that allows for specific properties of exchange rates. Again, we use the estimates for the purpose of comparison.

The remainder of this paper is organized as follows. In section 2 we introduce the methodology used. Section 3 describes the data, while in Section 4 we present results. Brief comments conclude. Technical details are given in Appendix A.

\section{Methodology}

The currency markets of Central Europe are usually not covered well in empirical finance literature. The research dealing with emerging markets concentrates mainly on the "old" emerging markets, e.g. Indonesia, Mexico, Thailand, etc. and "new" emerging markets are largely neglected. The lack of studies thus offers few hints on specifications of the drift and diffusion functions and misspecification problems can be an important issue. For this reason other specifications that enable one to capture volatility should be used.

Andersen, Bollerslev, Diebold and Labys (2001) list three ways to approximate an otherwise unobservable volatility. A volatility which is inherently unobservable can be obtained by (a) fitting parametric econometric models such as generalized autoregressive conditional heteroscedasticity $(\mathrm{GARCH})$, (b) by calculating volatility implied by option 
prices, or c) by calculating direct indicators of volatility such as ex post squared or absolute returns. ${ }^{3}$

In our analysis we use (1) a parametric model where volatility is perceived as square returns of exchange rate after filtering out interest rate changes (residual volatility not caused by interest rate changes) and (2) by fitting a parametric GARCH-in-mean model for exchange rate changes. Since the option price data for Central European currencies are not available for the early stages of the transition process marked by under-developed financial markets we are unable to use the approach of calculating volatility implied by option prices.

\subsection{Squared returns specification}

The diffusion function, as a proxy for volatility, can be estimated using the most general parametric specification of Ait-Sahalia (1996) that was developed to model the behavior of interest rates. The general parametric model gives more precise estimates on smaller data samples. In general, continuous time models for interest rate typically rest on one or more stationary diffusion processes with dynamics represented by Itô stochastic differential equation:

$$
d i_{t}=\mu\left(i_{t}\right) d t+\sigma\left(i_{t}\right) d W_{t},
$$

where $i_{t}$ is the interest rate, $\mu\left(i_{t}\right)$ is the drift function, $\sigma\left(i_{t}\right)$ is the diffusion function, and $\left\{W_{t}, t \geq 0\right\}$ is a standard Brownian motion. Usually, functions for drift and diffusion are parameterized. Particular models differ in the shape of drift, but mainly differ in the shape of the diffusion function. The Ait-Sahalia (1996) model offers quite a rich parametric specification as follows:

$$
\begin{aligned}
& \mu(i, \alpha)=\alpha_{0}+\alpha_{1} i_{t}+\alpha_{2} i_{t}^{2}+\frac{\alpha_{3}}{i_{t}} \\
& \sigma^{2}(i, \beta)=\beta_{0}+\beta_{1} i_{t}+\beta_{2} i_{t}^{\beta_{3}} .
\end{aligned}
$$

By imposing restrictions on parameters' values such specification could encompass many earlier models. For example, restriction $\alpha_{2}=\alpha_{3}=\beta_{1}=\beta_{2}=\beta_{3}=0$ would yield the Vasicek

\footnotetext{
${ }^{3}$ All of these approaches have some weaknesses and authors propose to use a new volatility measure, which they call "realized volatility". They compute daily realized volatility by summing intraday squared returns. However, the weakness of this measure rests in the fact that it is limited to data with intraday frequency.
} 
(1977) model. On the other hand, the Cox, Ingersoll and Ross (1985) model can be obtained by imposing the restriction $\beta_{3}=1 .{ }^{4}$

Ait-Sahalia (1996) argues that his specification proposed for interest rates can be extended to estimate mean and volatility of exchange rates. We believe that such an extension is not as straightforward as suggested. The model is specified so as to comply with the desired properties of level stationary time series (interest rate). The exchange rate is usually level non-stationary, but the first log-differences (or returns) are considered as stationary time series. Therefore, the properties of the model for exchange rate are very different from the model for interest rate and the Ait-Sahalia (1996) rich specification is not directly applicable. Thus, in the spirit of Ait-Sahalia's rich specification we develop a model using the concept of interest rate parity as a background motivation (Keynes 1923). Our specification models the change in the exchange rate in the following form for drift and diffusion functions:

$$
\begin{aligned}
& \mu(\Delta S, \alpha)=\alpha_{1}\left(i_{t}-i_{t}^{*}\right)+\alpha_{2}\left(\frac{i_{t}^{2}}{2}-\frac{i_{t}^{* 2}}{2}\right)+\alpha_{3}\left(\frac{i_{t}^{3}}{3}-\frac{i_{t}^{* 3}}{3}\right)+\varepsilon_{t} \\
& \sigma^{\prime 2}(\Delta S, \beta)=\beta_{0}+\beta_{1}\left(i_{t}-i_{t}^{*}\right)^{2}+\eta_{t}
\end{aligned}
$$

where $S$ is a $\log$ price of foreign currency in terms of domestic currency, $i_{t}$ is domestic interest rate, and $i_{t}{ }^{*}$ is foreign interest rate. The formal derivation of the model specification is given in Appendix A.

The richly specified $\mu$ and $\sigma^{2}$ functions of the spot exchange rate have not been introduced previously in the related literature. Moreover, the empirical evidence so far suggests that misspecification of the models in the literature is caused jointly by the linearity of the drift and constant diffusion. These are the two main reasons why we opt for rich nonlinear parametric specification of the drift (mean) and diffusion (volatility) functions as above.

The specification of drift uses higher order terms of Taylor expansion of interest rate parity condition. In the literature, it is normal to use only the first order approximation, but since we use countries with higher interest rates (sometimes $40 \%$ p.a.), the higher order terms are appropriate. ${ }^{5}$ Further, we approximate volatility as a nonlinear function of interest rate

\footnotetext{
${ }^{4}$ Recently Elerian, Chib and Shephard (2001) introduced a new methodology to estimate nonlinear stochastic differential equations when observations are discretely sampled. This methodology is able to increase the precision of estimates in cases where one is left with low number of observations. They compare estimates from their specification with that of Ait-Sahalia (1996) and find that their estimates perform well even in smaller data samples.

${ }^{5}$ It is possible to separate the interest rate differential into two variables - domestic and foreign interest rate. By separating them we would allow domestic and foreign interest rates to have different impacts on the exchange
} 
differential. This approach is similar to Bilson (1999). He argues that the volatility is related to the difference between the interest rates on the two currencies. The large interest rate differentials can only exist in the presence of high currency volatility, otherwise arbitrage opportunities would arise. Many empirical studies base their results on reporting standard deviation as a proxy for volatility (see Hallett and Anthony 1997, among others). We believe that such an approach is overly simplistic and that neglecting the role of interest rate can cause biased results.

Interest rate parity as a background motivation for our specification is a concept challenged by empirical literature. In early papers, we can find a rejection of this hypothesis (Fama 1984 and Frankel and Froot 1987, among others). Baille and Bollerslev (2000) claim that failure to find evidence for the presence of the interest rate parity condition can be due to wrong statistical modeling. They run a simulation exercise using data generated under the validity of uncovered interest rate parity. The simulation leads to the results reported in the empirical literature, namely rejection of hypothesis. Later, more advanced econometric methodologies display evidence in favor of interest rate parity. Kirikos (2002) tests the uncovered parity hypothesis, based on the cross-equation restrictions on a Markov switching process. He finds that the parity relationship cannot be rejected for three European currencies vis-à-vis the US dollar. Bansal and Dahlquist (2000) list other factors that can influence the validity of uncovered interest rate parity (UIP). These factors can be per-capita GNP, average inflation rates, or inflation volatility. The recent Flood and Rose (2002) study shows that UIP works better on average in the 1990s than in previous periods.

We advocate the use of UIP for the above model specification by the fact that under a currency basket-peg type of exchange rate regime the exchange rate is free to adjust to a smaller or larger extent. This feature is even more pronounced under a crawling or adjustable currency basket peg. This corresponds to the arrangements in both the Snake and Visegrad countries as we describe above. During the period when the ERM was in place serious pressures on exchange rates were followed by a depreciation in the form of devaluation or realignment. In the Visegrad countries exchange rates in Poland and Hungary depreciated by definition due to crawling or adjustable types of exchange rate regime. Exchange rates in

rate. This approach can be found in Svensson (1993) or Rose and Svensson (1994). In these studies the authors estimate the foreign interest rate to have a higher impact on exchange rate return than domestic. However, they did not conduct a statistical test for the equality of these two coefficients. The standard errors of coefficients are high enough to assume equality. We decide to use the differential, because the RHS variable (differential) should be integrated of the same order (zero order) as LHS variable (exchange rate return). We use this data transformation under the assumption that the change in domestic and foreign interest rate would have same impact on the exchange rate and only the level of interest rate differential plays an important role. 
Slovakia and the Czech Republic experienced pressure that built up over time and eventually depreciated after approaching the upper limit of the fluctuation band. Thus, evidence justifies connecting our specification with interest rate parity even for periods when exchange rates of both groups of countries were not fully floating.

The estimation of the model is performed in two steps using the feasible generalized least squares, the same estimation procedure as in Ait-Sahalia (1996). First we estimate the discretized version of the drift equation (1) in the form:

$$
E\left[\ln \left(S_{t+1}\right)-\ln \left(S_{t}\right) \mid S_{t}\right]=\alpha_{1}\left(i_{t}-i_{t}^{*}\right)+\alpha_{2}\left(\frac{i_{t}^{2}}{2}-\frac{i_{t}^{* 2}}{2}\right)+\alpha_{3}\left(\frac{i_{t}^{3}}{3}-\frac{i_{t}^{* 3}}{3}\right) .
$$

The squared residuals $\varepsilon_{t+1}^{2}$ from this first-stage regression are then regressed by least squares, with a discretized version of the diffusion equation (2) in the form:

$$
E\left[\varepsilon_{t+1}^{2} \mid S_{t}\right]=\beta_{0}+\beta_{1}\left(i_{t}-i_{t}^{*}\right)^{2} .
$$

The second-stage regression for the drift uses the fitted values from the diffusion regression to form the weighting matrix for the generalized least-squares estimation of discretized drift. ${ }^{6}$ In other words, we estimate the drift equation using variance-weighted least squares. This method differs from OLS in that homogeneity of variance is not assumed - the conditional variance of the dependent variable in the drift equation is estimated prior to the regression and varies by observation. Then, we treat this estimated variance as if it were the true variance when we compute standard errors in the drift equation.

The method of generalized least-squares estimation assumes the following model:

$$
y_{i}=x_{i} \beta+\varepsilon_{i},
$$

where the errors $\varepsilon_{i}$ are independent normal random variables with the distribution $\varepsilon_{i} \propto N\left(0, \sigma_{i}\right)$. The independent variables $x_{i}$ are assumed to be known without error. Let $s_{1}, s_{2}, \ldots, s_{n}$ be the assumed conditional standard deviation of $y_{i}$. Let $V=\operatorname{diag}\left(s_{1}^{2}, s_{2}^{2}, \ldots s_{n}^{2}\right)$ denote the estimate of the variance of $y$. Then the estimated regression coefficients are $b=\left(X^{\prime} V^{-1} X\right)^{-1} X^{\prime} V^{-1} y$.

\subsection{Leverage GARCH specification}

\footnotetext{
${ }^{6}$ For details see Kmenta (1990).
} 
The second approach for volatility modeling is the fitting of a specific parametric econometric model of the GARCH type. In the literature on the modeling of financial time series, and exchange rate especially, it is common to model the exchange rate changes as a GARCH $(1,1)$ process. This rather simple specification is enough to capture the basic properties of financial time series. Naturally, there are many other, more sophisticated, versions of GARCH which are able to explain other non-normalities of certain time series. However, empirically, many series with a conditionally heteroscedastic disturbances have been found to be adequately modeled with $\operatorname{GARCH}(1,1)$ specification:

$$
\begin{aligned}
& r_{t}=a_{0}+\sum_{i=1}^{k} a_{i} r_{t-i}+\varepsilon_{t} ; \varepsilon_{t} \sim N\left(0, \sigma_{t}^{2}\right) \\
& \sigma_{t}^{2}=\omega+\alpha \varepsilon_{t-1}^{2}+\beta \sigma_{t-1}^{2}
\end{aligned}
$$

where $r_{t}$ is the exchange rate change over two consecutive trading days, and $k$ is the number of lags chosen by a certain lag selection criterion. Under the condition of stationarity, e.g. the roots of the characteristic equation lie outside the unit circle, the errors $\varepsilon_{t}$ have the expected value of zero and are independent over time.

One of the areas addressed by many of the alternate specifications is asymmetry. GARCH specification implies a symmetric impact of innovations on volatility. Whether innovation $\varepsilon_{t-1}{ }^{2}$ is positive or negative makes no difference on the expected variance in the ensuing period, only the size of the innovation matters - simply speaking it means that good news and bad news have the same effect. The theory of leverage effect, first described in Black (1976) on the stock market, suggests a different impact of positive and negative innovations. The large unanticipated drop in the market is expected to lead to higher volatility than a large unanticipated increase. Therefore, we augment GARCH specification by a leverage dummy, $d_{t}$, to allow for innovation to have asymmetric effect on conditional volatility. It results in the following specification:

$$
\begin{aligned}
& r_{t}=a_{0}+\sum_{i=1}^{k} a_{i} r_{t-i}+\varepsilon_{t} ; \varepsilon_{t} \sim N\left(0, \sigma_{t}^{2}\right) \\
& \sigma_{t}^{2}=\omega+\alpha \varepsilon_{t-1}^{2}+\beta \sigma_{t-1}^{2}+\xi d_{t-1} \varepsilon_{t-1}^{2}
\end{aligned}
$$

where the dummy variable $d_{t-1}$ is equal to 1 if $\varepsilon_{t-1}<0$ and 0 otherwise; $r_{t}$ is the exchange rate change over two consecutive trading days, and $k$ is the number of the lags chosen by Schwarz-Bayesian lag selection criterion. The specification of volatility with leverage effect (represented by the dummy variable $d_{t-1}$ ) was introduced by Glosten, Jagannathan, and 
Runkle (1993) and applied for example by Engle and Ng (1993) and Hamilton and Susmel (1994) on asset prices or by Kočenda (1998) on exchange rates. ${ }^{7}$

A negative value of the coefficient $\xi$ would imply that negative news (innovation) increases the subsequent volatility of the exchange rate more than positive news (innovation). The value of the statistically significant leverage coefficient $\xi$ then indicates the magnitude of the leverage effect, and the sign its direction. A positive value of the coefficient $\xi$ indicates an increase - and a negative coefficient a decrease - in subsequent volatility of the exchange rate. By comparing values and signs of statistically significant leverage coefficients for a particular exchange rate in the two separate periods of tighter and looser exchange rate regime, it is possible to comment on the effect of the exchange regime on volatility. ${ }^{8}$

The estimation of the model is performed by using a log-likelihood function of the form $\ln L_{t}=-\frac{1}{2}\left(\ln \left(2 \pi \sigma_{t}^{2}\right)+\sum_{t=t_{0}}^{T} \frac{\varepsilon_{t}^{2}}{\sigma_{t}^{2}}\right) \cdot{ }^{9}$ The maximum likelihood estimates were obtained by using a numerical optimization algorithm described by Berndt, Hall, Hall and Hausman (1974).

\section{Data}

For the purpose of comparative analysis we use two groups of countries with similar economic and institutional developments with respect to exchange rate regime. In the case of the EMS countries we use the group of countries that adopted a tight exchange rate regime even prior to the EMS. This group of countries, the so-called "Snake", consists of Germany, the Netherlands, Belgium, and Denmark; it also included France on several occasions. In 1973, these countries fixed their exchange rates with each other while jointly floating against other countries. In 1979 these countries were among the founders of the EMS and during its history never deviated from the ERM. For this reason we consider this group as a benchmark

\footnotetext{
${ }^{7}$ The leverage effect was analyzed in stock price movements. For example, in the case of equities, Black (1976) and Nelson (1991), among others, argued that a stock price decrease tends to increase subsequent volatility more than would a stock price increase of the same magnitude. In the case of the exchange rate, the leverage effect represents the fact that a decrease in the price of a foreign currency in terms of domestic currency, or domestic currency's appreciation, would tend to increase the subsequent volatility of the domestic currency more than would a depreciation of an equal magnitude. Despite the fact that holding a foreign exchange is similar, in terms of risk, to holding equities, the literature dealing with the "leverage effect" in the context of exchange rate fluctuation is still lacking.

${ }^{8}$ In an earlier version of this paper, we used a model with a variance in mean equation. However, the variable turned out to be insignificant, and therefore, we opt for the model without a variance in mean equation.

${ }^{9}$ Suggested in Bollerslev (1986).
} 
case. ${ }^{10}$ In 1993 all countries widened their fluctuation band and from this year on we can consider their arrangement as a floating exchange rate system.

Potentially, there is another factor that could influence the exchange rate volatility, namely the credibility of the ERM arrangement. As we already mentioned in the Introduction, Krugman (1991) justifies the existence of the link between the width of the fluctuation band and the credibility of the arrangement. He considers the causality running from the width of band to credibility. Unfortunately, the credibility could be influenced by other factors than width of fluctuation band, for example the interest rate differential, inflation rate differential, or the level of foreign reserves. That is why we choose countries (Snake) that have the highest credibility among the ERM countries and enjoyed this reputation over the whole time span. By including the countries that were forced to re-align the central parity many times we would face the problem of the inclusion of a credibility variable in our model. August 1993 is the indisputable date when the exchange rate fluctuation band was significantly increased and credibility probably as well. The change in credibility, however, was not so pronounced for the Snake countries as for the other ERM countries. According to Ledesma-Rodrigues et al. (2003) the biggest changes in credibility occurred during the 1980s and in 1993. Moreover, for Belgium and the Netherlands the change did not occur even in 1993. For other ERM countries, the width of the band brought an increase in credibility. It is important that there was no other substantial change in credibility that was caused by any other factor than broadening of the band. The careful choice of countries with similar credibility should diminish the effect of credibility on exchange rate in our analysis.

As for the Central European countries we chose the Visegrad Four group that consists of the Czech Republic, Hungary, Poland, and Slovakia. As early as December 1991, the former Czechoslovakia, Poland and Hungary signed the "European Agreements" with the European Union. These countries have striven to establish a workable framework for international trade and co-operation in order to facilitate the transition process. Their effort was institutionalized in March 1993 in the form of the Central European Free Trade Agreement (CEFTA) that was signed also by Slovenia. ${ }^{11}$

\footnotetext{
${ }^{10}$ Kočenda and Pappel (1997) find that countries which continuously participated in the narrow ERM band show a dramatically higher convergence rate of inflation during the ERM period than those staying outside the mechanism. They credit this fact to the disciplining effect of the ERM. For details see also Giavazzi and Giovanninni (1989).

${ }^{11}$ Kočenda (2001) examines the macroeconomic convergence of Central European countries. He finds that the group of five countries that signed the original CEFTA agreement (the Visegrad group is a subset of CEFTA countrywise) display similar and relatively high degrees of convergence in macroeconomic fundamentals. He
} 
We use nominal exchange rates expressed in terms of the Deutsche mark (or Euro) to calculate changes in exchange rate over two consecutive periods. We use interest rates of one-month maturity to calculate the needed interest rate differentials. In the literature we may also find shorter maturities used, however, one-month maturity is the maturity that is published in each country for the longest period. It is also a standard reference interest rate for most central banks. The basic statistics for exchange rate changes are in Table 1 and for interest rates in Table 2.

The motivation for our comparison lies in a change from one exchange rate regime to another. The date of change from fixed to floating exchange rate regime is our anchor date. For Snake countries it is uniformly August 2, 1993. However, for Visegrad Four countries the day when countries changed their exchange rate regimes are different. The national banks introduced a floating regime on the following dates: May 26, 1997 in the Czech Republic, October 2, 1998 in Slovakia, and April 12, 2000 in Poland. In the case of Poland, we can consider a close parallel to the post-1993 development of the EMS. Poland introduced a wide fluctuation band of $\pm 15.0 \%$ (same as the EMS) on March 25, 1999. The same development is found in Hungary where the band was widened also to $\pm 15.0 \%$ on May 4, 2001 and no further monthly devaluations were implemented.

Since the decisive point in time is the date of change from a fixed to floating regime, the time span for Snake countries begins on January 1, 1988 (5 years prior to the change) and lasts until December 31, 1998 (5 years after the change). As for the Visegrad countries we use the maximum length available prior and post to the change of regime, namely the data from January 1993 to July 2002.

The institutional set-up goes beyond the exchange rate arrangement. It involves, among others, the degree of credibility, the independence of the monetary authority, the existence of targeting mechanisms (inflation, monetary aggregates), and, for the specific sample of CEFTA countries, the process of EU accession, and eventually ERM/Euro zone membership, with the same sort of expectation effects observed in the ERM/Euro zone changeover. The effects of these factors on exchange rates are covered in great detail in Vinhas de Souza (2002a). He finds that, for a sample of accession countries, a credible, independent central bank with a floating exchange rate and a targeting mechanism mimics the nominal variability (including exchange rate) properties of a truly fixed exchange rate

attributes this finding to two factors. First, international trade within the CEFTA framework serves as a natural means of coordinating economic development. Second, the prospective accession to the EU serves as an institutional means of coordination in order to satisfy a set of pre-accession criteria. 
regime. This result supports the hypothesis that the volatility of exchange rate is also affected by other institutional factors, not only the exchange rate regime. ${ }^{12}$ But again as we mention above on the credibility issue, we choose those CEE countries that have very similar evolution of institutional setup over the last 10 years. It is not only a common change from fixed to floating exchange rate regime, but also similar (or same) quality of monetary authorities, transition experience, timing of EU accession process, EU entry, and finally the expected date of Euro area membership.

The change of the exchange rate regime (or its important modification) represents a certain shock for the currency markets. Traders and central banks during the time before and shortly after the change react differently than during a "normal" period. During this period the exchange rate series have different statistical properties and contain many outliersobservations that do not come from the usual data-generating process. Therefore, we decided not to include the month when the change occurred or one month after the change (or modification) of exchange rate regime in our dataset. Our results should not contain any bias coming from turbulent times.

\section{Empirical Results}

\subsection{Squared returns}

As a first step we estimated the model for mean (1) where squared residuals from this regression represent volatility. Then we estimate equation (2). First we present results for the Visegrad Four currencies, separately for the periods of different exchange rate regimes. The results are in Table 3 Panel A. Then we present the results for the Snake currencies in Table 3 Panel B.

Because of the change in exchange rate regime, we expect the parameters of the drift and diffusion to be different during different regimes. Specifically, the particular parameterization is not time-homogenous. For example, the coefficient $\alpha_{1}$ of the process estimated during a floating regime should be different than that estimated during the fixed regime. Unfortunately, a lack of statistical significance precludes making an unambiguous conclusion with respect to both groups of currencies. The lack of significance is present for other coefficients of the mean function as well.

The most important and illustrative part of the estimation are the values of the coefficients in the volatility function. Among them the coefficient $\beta_{0}$ plays a pivotal role. This

\footnotetext{
${ }^{12}$ We would like to thank Prof. Vinhas de Souza for pointing out this issue.
} 
coefficient captures the extent of volatility that does not depend on fluctuations in interest rate differential. The other coefficient $\left(\beta_{1}\right)$ portrays the volatility movements dependent on these fluctuations. The statistical significance of coefficient $\beta_{0}$ allows us to make several interesting conclusions. Volatility during a "fixed" regime period is uniformly higher in Visegrad Four currencies than in Snake currencies. Volatility during a "floating" regime period is also uniformly higher in Visegrad Four currencies than in Snake currencies.

When we compare changes in magnitude of volatility between periods of fixed and floating regimes the following findings emerge. The Snake currencies exhibit a decrease in volatility. As for the Visegrad Four currencies, all show a moderate increase in volatility. The result for the Hungarian forint is inconclusive due to lack of statistical significance during the fixed regime period.

It is worth mentioning how the volatility depends on the (square of the) interest rate differential. For the Visegrad countries (except Poland) we find a positive significant relation regardless of the type of exchange rate regime. In the case of Snake countries, during the fixed exchange rate regime, the size of the interest rate differential is not significant, with the exception of the Danish koruna. After the introduction of a floating regime, the relationship is again significantly positive. Bilson (1999) finds similar results using the three world major exchange rates.

\subsection{Leverage GARCH}

We employ a maximum likelihood method in order to estimate the coefficients of equation (6). The results are in Table 4. Panel A captures Visegrad Four countries and Panel B Snake countries.

For all Visegrad Four countries, with the exception of Hungary, we find support for the random walk hypothesis of exchange rate returns and predictability of volatility. This finding is in accord with established stylized facts in the literature. On the other hand, we detect significant autocorrelation in returns for Snake countries that refutes the hypothesis of random walk, while the predictability of volatility is again confirmed.

When we compared the values and significance of the leverage effect coefficients we found the results for the Snake countries to be mixed. In the case of the Belgian and French frank we detect a decrease in volatility, while for the Danish crown we detect a slight increase in volatility and for the Netherlands gulden results are inconclusive due to lack of significance of coefficient.. Results for Visegrad Four countries uniformly show an increase in volatility during the floating regime period. 
In general, results from both methods lead to the conclusion that the width of the fluctuation band, either narrow or broad, does not necessarily mean an unambiguous influence on exchange rate fluctuation. There can be various factors that affect the volatility of exchange rate other than the type of exchange rate regime. However, the type of regime is most probably the strongest factor. In our analysis we try to isolate this effect and to assess its importance. The identification and evaluation of other factors is a topic for further research.

\section{Conclusions}

We analyzed the volatility of the exchange rates of the Central European countries (Visegrad group) and a selected group of European Union countries (the Snake) participating in the former European Monetary System.

Our methodology consisted of two different approaches. The parametric approach uses the theoretical assumption of UIP and the second approach uses a more traditional time series approach in the form of GARCH specification. Results from the first approach can be used for policy decision making, while the second focuses solely on the time series as such without any economic theory in the background. Both have strengths and weaknesses, which is why we opt for both.

We compared volatilities in the currencies of both groups under specific exchange rate regimes. The currencies of the Snake countries exhibit lower volatility than currencies of the Visegrad countries under both fixed and floating regimes. After the change in exchange regime has taken place, volatility for the Visegrad Four currencies increased uniformly. The case of the Snake countries exhibits mixed results. The volatility of some currencies has decreased or increased.

We base our conclusions on results produced by two different approaches to modeling exchange rate volatility. Both methods provide identical results for the currencies of the Visegrad Four group: an increase in volatility after the floating exchange rate regime was introduced. Both methods also provide identical results for half of the Snake currencies (decrease of volatility after floating was adopted) but leave some ambiguity since for two currencies the results are not consistent. Our robust findings can be used to compare the prospects of candidate countries (Visegrad Fourgroup) with respect to exchange rate policies during the pre-accession period and especially during the period prior to entering the EMU. 


\section{Appendices}

\section{Appendix A}

In this appendix we derive the mean and volatility specifications. We begin with the conventional notion of the interest rate parity in the form:

$\frac{F}{S}\left(1+i^{*}\right)=(1+i)$, where $\mathrm{S}$ is exchange rate at time $t, \mathrm{~F}$ is the exchange rate at time $t+1, i$ is the domestic interest rate, and $i^{*}$ is the foreign interest rate. Taking the natural log of the above results in $\ln \frac{F}{S}=\ln \frac{(1+i)}{\left(1+i^{*}\right)}$, this can be further rewritten as $\ln F-\ln S=\ln (1+i)-\ln \left(1+i^{*}\right)$

Taylor expansion of $\ln (1+x)=x-\frac{x^{2}}{2}+\frac{x^{3}}{3}-\frac{x^{4}}{4}+\frac{x^{5}}{5}+\ldots$ if $-1<x \leq 1$ can be used to express the inter-period change in exchange rate as

$d \ln S=i-\frac{i^{2}}{2}+\frac{i^{3}}{3}+o\left(i^{4}\right)-\left(i^{*}-\frac{i^{* 2}}{2}+\frac{i^{* 3}}{3}+o\left(i^{* 4}\right)\right)$. After rearranging the terms and neglecting the fourth and higher order terms we obtain the expression of inter-period change in exchange rate as a function of domestic and foreign interest rate:

$d \ln S=i-i^{*}-\left(\frac{i^{2}-i^{* 2}}{2}\right)+\left(\frac{i^{3}-i^{* 3}}{3}\right)$. This is our mean (drift) equation.

For specification of volatility, we approximate volatility as a nonlinear function of interest rate differential. Hence, our specification of mean and volatility results in the following pair of equations:

$$
\begin{aligned}
& \mu(\Delta S, \alpha)=\alpha_{1}\left(i_{t}-i_{t}^{*}\right)+\alpha_{2}\left(\frac{i_{t}^{2}}{2}-\frac{i_{t}^{* 2}}{2}\right)+\alpha_{3}\left(\frac{i_{t}^{3}}{3}-\frac{i_{t}^{* 3}}{3}\right)+\varepsilon_{t} \\
& \sigma^{\prime 2}(\Delta S, \beta)=\beta_{0}+\beta_{1}\left(i_{t}-i_{t}^{*}\right)^{2}+\eta_{t} .
\end{aligned}
$$


William Davidson Institute Working Paper 622

Appendix B

Table 1

Exchange Rate Regimes Development

A: Czech Republic

Alterations of koruna exchange regime

\begin{tabular}{|l|l|}
\hline 1 January 1991 & $\begin{array}{l}\text { Currency basket peg regime, Basket: 45.52\% DEM, 31.34\% USD, } \\
12.35 \% \text { ATS, 4.24\% GBP, 6.55\% CHF }\end{array}$ \\
\hline 2 January 1992 & $\begin{array}{l}\text { Change in Basket composition: 36.15\% DEM, 49.07\% USD, } \\
8.07 \% \text { ATS, 2.92\% FRF, 3.79\% CHF }\end{array}$ \\
\hline 8 February 1993 & $\begin{array}{l}\text { Split of Czechoslovak currency - Czech koruna. No change in } \\
\text { basket composition or band width }\end{array}$ \\
\hline 3 May 1993 & Basket 65\% DEM, 35\% USD, Band $\pm 0.5 \%$ \\
\hline 28 February 1996 & Widening band to $\pm 7.5 \%$ \\
\hline 26 May 1997 & $\begin{array}{l}\text { Introduction of managed float with reference currency DEM and } \\
\text { later EUR }\end{array}$ \\
\hline
\end{tabular}

B: Poland

Changes of zloty exchange regime

\begin{tabular}{|c|c|}
\hline 1 January 1990 & Exchange rate fixed to dollar. $1 \mathrm{USD}=9500 \mathrm{ZLP}$ \\
\hline 16 May 1991 & $\begin{array}{l}\text { Exchange rate fixed to a currency basket ( } 45 \% \text { USD, } 35 \% \text { DEM, } \\
10 \% \mathrm{GBP}, 5 \% \mathrm{FRF}, 5 \% \mathrm{CHF}) \text {, devaluation to } 1 \mathrm{USD}=11100 \mathrm{ZLP} \\
(16.84 \%)\end{array}$ \\
\hline 14 October 1991 & $\begin{array}{l}\text { Crawling peg to the currency basket: crawling rate } 1.8 \% \text { monthly, } \\
\text { NBP margin }+/-0.6 \%\end{array}$ \\
\hline 26 February 1992 & Devaluation by $12 \%+$ maintain crawling peg $1.8 \%$ \\
\hline 27 August 1993 & Devaluation by $7.4 \%+$ Crawling rate $1.6 \%$ \\
\hline 13 September 1994 & Crawling peg $1.5 \%$ monthly \\
\hline 30 November 1994 & Crawling peg $1.4 \%$ \\
\hline 16 February 1995 & Crawling peg $1.2 \%$ \\
\hline 6 March 1995 & NBP margin $+/-2 \%$ \\
\hline 16 May 1995 & $\begin{array}{l}\text { Introduction of crawling band }+/-7 \% \text {, crawling rate } 1.2 \% \text {, } \\
\text { interbank rates subject to free market forces and NBP } \\
\text { intervention }\end{array}$ \\
\hline 22 December 1995 & Revaluation by $6 \%$ \\
\hline 8 January 1996 & Crawling peg $1.0 \%$ \\
\hline 26 February 1998 & Crawling peg $0.8 \%$ and band $+/-10 \%$ \\
\hline 17 July 1998 & Crawling peg $0.65 \%$ \\
\hline 10 September 1998 & Crawling peg $0.5 \%$ \\
\hline 28 October 1998 & Band $+/-12.5 \%$ \\
\hline 1 January 1999 & Change in currency basket: euro $55 \%$, dollar $45 \%$ \\
\hline 25 March 1999 & Crawling peg $0.3 \%$, band $+/-15 \%$ \\
\hline 7 June 1999 & NBP is not obliged to perform transactions with commercial \\
\hline
\end{tabular}


William Davidson Institute Working Paper 622

\begin{tabular}{|l|l|}
\hline & banks during fixing \\
\hline 12 April 2000 & Floating exchange rate \\
\hline
\end{tabular}

\section{C: Hungary}

Changes in basket and width of the forint intervention band

\begin{tabular}{|l|l|}
\hline 26 February 1990 & USD 42,6\%, DEM 25,6\%, ATS 10,4\%, CHF 4,9\%, ITL 3,8\%, \\
& FRF 3,5\%, GBP 2,9\%, SEK 2,0\%, NLG 1,7\%, FIM 1,5\%, BEC \\
& $1,1 \%$ \\
\hline 14 March 1991 & USD 50,9\%, DEM 23,1\%, ATS 8,1\%, CHF 3,9\%, ITL 3,5\%, FRF \\
& $3,6 \%$, GBP 2,7 \%, SEK 1,5\%, NLG 2,7\% \\
\hline 9 December 1991 & USD 50\%, ECU 50\% \\
\hline 1 July 1992 & Band width $\pm 0.3 \%$ \\
\hline 2 August 1993 & USD 50\%, DEM 50\% \\
\hline 16 May 1994 & USD 30\%, ECU 70\% \\
\hline 1 June 1994 & Band width $\pm 0.5 \%$ \\
\hline 5 August 1994 & Band width $\pm 1.25 \%$ \\
\hline 22 December 1994 & Band width $\pm 2.25 \%$ \\
\hline 1 January 1997 & USD 30\%, DEM 70\% \\
\hline 1 January 1999 & USD 30\%, EUR 70\% \\
\hline 1 January 2000 & EUR 100\% \\
\hline 4 May 2001 & Band width $\pm 15.00 \%$ \\
\hline
\end{tabular}

Official devaluations of forint

\begin{tabular}{|c|c|c|c|}
\hline 31 January 1990 & $1.0 \%$ & 29 November 1994 & $1.0 \%$ \\
\hline 6 February 1990 & $2.0 \%$ & 3 January 1995 & $1.4 \%$ \\
\hline 20 February 1990 & $2.0 \%$ & 14 February 1995 & $2.0 \%$ \\
\hline 7 January 1991 & $15.0 \%$ & 13 March 1995 & $9.0 \%$ \\
\hline 8 November 1991 & $5.8 \%$ & 16 March 1995 & $\begin{array}{r}1.9 \% \text { (rate of daily devaluation: } \\
0.060 \% \text { ) }\end{array}$ \\
\hline 16 March 1992 & $1.9 \%$ & 29 June 1995 & $\begin{array}{r}1.3 \% \text { (rate of daily devaluation: } \\
0.042 \% \text { ) }\end{array}$ \\
\hline 24 June 1992 & $1.6 \%$ & 2 January 1996 & $\begin{array}{r}1.2 \% \text { (rate of daily devaluation: } \\
0.040 \% \text { ) }\end{array}$ \\
\hline 9 November 1992 & $1.9 \%$ & 1 January 1997 & $\begin{array}{r}1.2 \% \text { (rate of daily devaluation: } \\
0.040 \% \text { ) }\end{array}$ \\
\hline 12 February 1993 & $1.9 \%$ & 1 April 1997 & $\begin{array}{r}1.1 \% \text { (rate of daily devaluation: } \\
0.036 \% \text { ) }\end{array}$ \\
\hline 26 March 19932 & $.9 \%$ & 15 August 1997 & $\begin{array}{r}1.0 \% \text { (rate of daily devaluation: } \\
0.033 \% \text { ) }\end{array}$ \\
\hline 7 June 1993 & $1.9 \%$ & 1 January 1998 & $\begin{array}{r}0.9 \% \text { (rate of daily devaluation: } \\
0.030 \% \text { ) }\end{array}$ \\
\hline 9 July 1993 & $3.0 \%$ & 15 June 1998 & $\begin{array}{r}0.8 \% \text { (rate of daily devaluation: } \\
0.026 \% \text { ) }\end{array}$ \\
\hline 29 September 1993 & $4.5 \%$ & 1 October 1998 & $\begin{array}{r}0.7 \% \text { (rate of daily devaluation: } \\
0.023 \% \text { ) }\end{array}$ \\
\hline 3 January 1994 & $1.0 \%$ & 1 January 1999 & $\begin{array}{r}0.6 \% \text { (rate of daily devaluation: } \\
0.020 \% \text { ) }\end{array}$ \\
\hline
\end{tabular}


William Davidson Institute Working Paper 622

\begin{tabular}{|c|c|c|c|}
\hline 16 February 1994 & $2.6 \%$ & 1 July 1999 & $\begin{array}{r}0.5 \% \text { (rate of daily devaluation: } \\
0.0163 \% \text { ) }\end{array}$ \\
\hline 13 May 1994 & $1.0 \%$ & 1 October 1999 & $\begin{array}{r}0.4 \% \text { (rate of daily devaluation: } \\
0.0133 \% \text { ) }\end{array}$ \\
\hline 10 June 1994 & $1.2 \%$ & 1 April 2000 & $\begin{array}{r}0.3 \% \text { (rate of daily devaluation: } \\
0.0098 \% \text { ) }\end{array}$ \\
\hline 5 August 1994 & $8.0 \%$ & 1 April 2001 & $\begin{array}{r}0.2 \% \text { (rate of daily devaluation: } \\
0.00654 \% \text { ) }\end{array}$ \\
\hline \multirow[t]{2}{*}{11 October 1994} & $1.1 \%$ & 1 October 2001 & No devaluation \\
\hline & & 4 June 2003 & $\begin{array}{r}\text { One time } 2.25 \% \text { devaluation of } \\
\text { central parity }\end{array}$ \\
\hline
\end{tabular}

D: Slovakia

Alterations of koruna exchange regime

\begin{tabular}{|l|l|}
\hline 1 January 1991 & $\begin{array}{l}\text { Currency basket peg regime, Basket: 45.52\% DEM, 31.34\% USD, } \\
12.35 \% \text { ATS, 4.24\% GBP, 6.55\% CHF }\end{array}$ \\
\hline 2 January 1992 & $\begin{array}{l}\text { Change in Basket composition: 36.15\% DEM, 49.07\% USD, } \\
8.07 \% \text { ATS, 2.92\% FRF, 3.79\% CHF }\end{array}$ \\
\hline 8 February 1993 & $\begin{array}{l}\text { Split of Czechoslovak currency - Slovak koruna, Basket: 36.16\% } \\
\text { DEM, 49.06\% USD, 8.07\% ATS, 2.92\% FRF, 3.79\% CHF, Band } \\
\pm 1.5 \%\end{array}$ \\
\hline 10 July 1993 & Devaluation 10\% \\
\hline 14 July 1994 & Basket changed: $60 \%$ DEM, 40\% USD \\
\hline 1 January 1996 & Band $\pm 3 \%$ \\
\hline 31 July 1996 & Band $\pm 5 \%$ \\
\hline 1 January 1997 & Band $\pm 7 \%$ \\
\hline 2 October 1998 & Introduction of managed float \\
\hline 1 January 1999 & Reference currency EUR \\
\hline
\end{tabular}




\section{William Davidson Institute Working Paper 622}

Table 1

Basic Statistics: Daily changes of local currency with respect to Deutsch mark

Fixed exchange rate regime

\begin{tabular}{|c|c|c|c|c|c|c|c|c|}
\hline & $\begin{array}{l}\text { Czech } \\
\text { koruna }\end{array}$ & $\begin{array}{l}\text { Slovak } \\
\text { koruna }\end{array}$ & $\begin{array}{r}\text { Polish } \\
\text { zloty }\end{array}$ & $\begin{array}{r}\text { Hungarian } \\
\text { forint }\end{array}$ & $\begin{array}{r}\text { Belgian } \\
\text { frank }\end{array}$ & $\begin{array}{r}\text { French } \\
\text { frank }\end{array}$ & $\begin{array}{r}\text { Netherland } \\
\text { gulden }\end{array}$ & $\begin{array}{l}\text { Danish } \\
\text { koruna }\end{array}$ \\
\hline No. of Obs. & 1048 & 684 & 864 & 1136 & 763 & 766 & 640 & 610 \\
\hline Mean & $1.15 \mathrm{E}-05$ & $5.09 \mathrm{E}-06$ & 7.97E-05 & $2.64 \mathrm{E}-04$ & 8.67E-06 & $5.46 \mathrm{E}-06$ & $-2.55 \mathrm{E}-05$ & $-2.27 \mathrm{E}-06$ \\
\hline Std. Deviation & 0.0029 & 0.0034 & 0.0066 & 0.0024 & 0.0022 & 0.0013 & 0.0007 & 0.0020 \\
\hline Mini & -0.0130 & -0.0384 & -0.0412 & -0.0143 & -0.0304 & -0.0160 & -0.0047 & -0.0164 \\
\hline Maxi & 0.0207 & 0.0157 & 0.0463 & 0.0164 & 0.0253 & 0.0082 & 0.0035 & 0.0108 \\
\hline Start & $01 / 1993$ & $07 / 1995$ & 08.1996 & $01 / 08 / 1996$ & $02 / 07 / 1990$ & 02/07/1990 & $02 / 01 / 1991$ & 13.02 .1991 \\
\hline End & $/ 1997$ & 09.1998 & 3.2000 & 27.04 .2001 & 29.07 .1993 & 29.07 .1993 & 29.07 .1993 & 29.07 .1993 \\
\hline \multicolumn{9}{|c|}{ Floating exchange rate regime } \\
\hline No1 & 1232 & 904 & 535 & 268 & 1298 & 1298 & 1298 & 1298 \\
\hline Mean & $-1.58 \mathrm{E}-04$ & $6.36 \mathrm{E}-05$ & $-7.94 \mathrm{E}-07$ & $2.13 \mathrm{E}-05$ & $-3.58 \mathrm{E}-05$ & $-3.48 \mathrm{E}-05$ & $1.63 \mathrm{E}-06$ & $-4.79 \mathrm{E}-05$ \\
\hline & 0.0046 & 0.0032 & 0.0084 & 0.0059 & 0.0011 & 0.0016 & 0.0004 & 0.0012 \\
\hline Minir & -0.0269 & -0.0155 & -0.0582 & -0.0204 & -0.0134 & -0.0104 & -0.0033 & -0.0088 \\
\hline Max & 0.0311 & 0.0248 & 0.0630 & 0.0439 & 0.0080 & 0.0087 & 0.0040 & 0.0093 \\
\hline & $/ 07 / 1997$ & $01 / 12 / 1998$ & $01 / 06 / 2000$ & $02 / 07 / 2001$ & $01 / 10 / 1993$ & $01 / 10 / 1993$ & $01 / 10 / 1993$ & 01/10/1993 \\
\hline End & 30.07 .2002 & 30.07 .2002 & 30.07 .2002 & 30.07 .2002 & 30.12 .1998 & 30.12 .1998 & 30.12 .1998 & 30.12 .1998 \\
\hline
\end{tabular}

Table 2

Basic Statistics: One-month interest rate on local currency

Fixed exchange rate regime

\begin{tabular}{|c|c|c|c|c|c|c|c|c|}
\hline & $\begin{array}{r}\text { Czech } \\
\text { koruna }\end{array}$ & $\begin{array}{l}\text { Slovak } \\
\text { koruna }\end{array}$ & $\begin{array}{r}\text { Polish } \\
\text { zloty }\end{array}$ & $\begin{array}{r}\text { Hungarian } \\
\text { forint }\end{array}$ & $\begin{array}{r}\text { Belgian } \\
\text { frank }\end{array}$ & $\begin{array}{r}\text { French } \\
\text { frank }\end{array}$ & $\begin{array}{r}\text { Netherland } \\
\text { gulden }\end{array}$ & $\begin{array}{l}\text { Danish } \\
\text { koruna }\end{array}$ \\
\hline No. of Obs. & 1048 & 684 & 864 & 1136 & 763 & 766 & 640 & 610 \\
\hline Mean & $11.1 \%$ & $14.9 \%$ & $19.8 \%$ & $16.7 \%$ & $9.1 \%$ & $10.0 \%$ & $8.9 \%$ & $11.8 \%$ \\
\hline Std. Deviation & $2.3 \%$ & $6.2 \%$ & $4.3 \%$ & $4.1 \%$ & $0.7 \%$ & $1.2 \%$ & $0.8 \%$ & $4.3 \%$ \\
\hline Minimum & $6.2 \%$ & $5.1 \%$ & $13.3 \%$ & $9.3 \%$ & $6.9 \%$ & $7.3 \%$ & $6.6 \%$ & $8.2 \%$ \\
\hline Max & $20.0 \%$ & $42.5 \%$ & $27.3 \%$ & $23.9 \%$ & $10.4 \%$ & $18.0 \%$ & $10.1 \%$ & $35.0 \%$ \\
\hline Start & $01 / 1993$ & $07 / 07 / 19951$ & 12.08 .1996 & $01 / 08 / 1996$ & $02 / 07 / 1990$ & $02 / 07 / 1990$ & $02 / 01 / 1991$ & 13.02 .1991 \\
\hline End & 9/04/1997 & 28.09 .19983 & 30.03 .2000 & 27.04 .2001 & 29.07 .1993 & 29.07.1993 & 29.07 .1993 & 29.07.1993 \\
\hline \multicolumn{9}{|c|}{ Floating exchange rate regime } \\
\hline Nom. of Observ. & 1232 & 904 & 535 & 268 & 1298 & 1298 & 1298 & 1298 \\
\hline Mean & $8.1 \%$ & $10.0 \%$ & $15.5 \%$ & $9.8 \%$ & $4.4 \%$ & $4.7 \%$ & $3.9 \%$ & $5.0 \%$ \\
\hline Std. Deviation & $4.5 \%$ & $3.4 \%$ & $3.6 \%$ & $1.1 \%$ & $1.4 \%$ & $1.5 \%$ & $1.0 \%$ & $1.4 \%$ \\
\hline Minimum & $3.1 \%$ & $7.6 \%$ & $8.8 \%$ & $8.5 \%$ & $3.1 \%$ & $3.3 \%$ & $2.7 \%$ & $3.6 \%$ \\
\hline Maxin & $22.7 \%$ & $30.0 \%$ & $20.6 \%$ & $11.6 \%$ & $10.2 \%$ & $9.0 \%$ & $6.5 \%$ & $9.8 \%$ \\
\hline Start & $/ 07 / 1997$ & $01 / 12 / 19980$ & $01 / 06 / 2000$ & $02 / 07 / 2001$ & $01 / 10 / 1993$ & $01 / 10 / 1993$ & $01 / 10 / 1993$ & $01 / 10 / 1993$ \\
\hline End & 30.07 .2002 & 30.07 .20023 & 30.07.2002 & 30.07 .2002 & 30.12 .1998 & 30.12 .1998 & 30.12 .1998 & 30.12 .1998 \\
\hline
\end{tabular}


William Davidson Institute Working Paper 622

Table 3.

Regression results of the equation:

$$
\begin{gathered}
\mu(\Delta S, \alpha)=\alpha_{1}\left(i_{t}-i_{t}^{*}\right)+\alpha_{2}\left(\frac{i_{t}^{2}}{2}-\frac{i_{t}^{* 2}}{2}\right)+\alpha_{3}\left(\frac{i_{t}^{3}}{3}-\frac{i_{t}^{* 3}}{3}\right) \\
\sigma^{2}(\Delta S, \beta)=\beta_{0}+\beta_{1}\left(i_{t}-i_{t}^{*}\right)^{2}
\end{gathered}
$$

\section{PANEL A: VISEGRAD COUNTRIES}

\begin{tabular}{|c|c|c|c|c|c|c|}
\hline Currency & $\alpha_{1}$ & $\alpha_{2}$ & $\alpha_{3}$ & $\beta_{0}$ & $\beta_{1}$ & $\begin{array}{l}\text { No. of } \\
\text { Obs. }\end{array}$ \\
\hline Czech koruna & $\begin{array}{l}0.010 \\
(0.027)\end{array}$ & $\begin{array}{l}0.087 \\
(0.601)\end{array}$ & $\begin{array}{r}-0.196 \\
(3.094)\end{array}$ & $\begin{array}{c}0.00079^{1} \\
(2.1 \mathrm{E}-4)\end{array}$ & $\begin{array}{l}0.3137^{1} \\
(7.5 \mathrm{E}-2)\end{array}$ & 1048 \\
\hline Slovak koruna & $\begin{array}{c}-0.058^{1} \\
(0.022)\end{array}$ & $\begin{array}{c}-1.270^{1} \\
(0.466)\end{array}$ & $\begin{array}{l}-6.069^{1} \\
(2.114)\end{array}$ & $\begin{array}{c}0.00110^{1} \\
(1.9 \mathrm{E}-4)\end{array}$ & $\begin{array}{l}0.0708^{1} \\
(2.0 \mathrm{E}-2)\end{array}$ & 438 \\
\hline Polish zloty & $\begin{array}{l}0.394 \\
(0.330)\end{array}$ & $\begin{array}{l}6.275 \\
(5.232)\end{array}$ & $\begin{array}{l}21.032 \\
(17.441)\end{array}$ & $\begin{array}{c}0.00345^{10} \\
(2.0 \mathrm{E}-3)\end{array}$ & $\begin{array}{l}0.1918^{1} \\
(6.7 \mathrm{E}-2)\end{array}$ & 163 \\
\hline Hungarian forint & $\begin{array}{r}-0.467 \\
(0.417)\end{array}$ & $\begin{array}{r}-7.054 \\
(6.113)\end{array}$ & $\begin{array}{r}-22.363 \\
(18.781)\end{array}$ & $\begin{array}{r}0.00425 \\
(4.6 \mathrm{E}-3) \\
\end{array}$ & $\begin{array}{l}0.1622 \\
(1.4 \mathrm{E}-1)\end{array}$ & 157 \\
\hline \multicolumn{7}{|c|}{ Floating exchange rate regime } \\
\hline Czech koruna & $\begin{array}{l}0.003 \\
(0.044)\end{array}$ & $\begin{array}{l}0.303 \\
(1.202)\end{array}$ & $\begin{array}{l}2.662 \\
(6.928)\end{array}$ & $\begin{array}{c}0.00395 \\
(4.3 \mathrm{E}-4)\end{array}$ & $\begin{array}{l}0.3241 \\
(7.0 \mathrm{E}-2)\end{array}$ & 1232 \\
\hline Slovak koruna & $\begin{array}{l}0.008 \\
(0.022)\end{array}$ & $\begin{array}{l}0.195 \\
(0.509)\end{array}$ & $\begin{array}{l}1.197 \\
(2.437)\end{array}$ & $\begin{array}{c}0.00128^{1} \\
(3.5 \mathrm{E}-4)\end{array}$ & $\begin{array}{l}0.2381^{1} \\
(8.4 \mathrm{E}-2)\end{array}$ & 903 \\
\hline Polish zloty & $\begin{array}{l}0.067 \\
(0.227)\end{array}$ & $\begin{array}{l}1.178 \\
(4.641)\end{array}$ & $\begin{array}{r}4.430 \\
(20.758)\end{array}$ & $\begin{array}{c}0.01992 \\
\\
(3.5 \mathrm{E}-3)\end{array}$ & $\begin{array}{r}-0.1671 \\
(1.5 \mathrm{E}-1)\end{array}$ & 533 \\
\hline Hungarian forint & $\begin{array}{r}-0.305 \\
(2.143) \\
\end{array}$ & $\begin{array}{l}-8.647 \\
(63.216) \\
\end{array}$ & $\begin{array}{r}-55.905 \\
(430.394) \\
\end{array}$ & $\begin{array}{c}0.00996^{10} \\
(5.2 \mathrm{E}-3)\end{array}$ & $\begin{array}{l}4.77488^{1} \\
(1.8 \mathrm{E}+0) \\
\end{array}$ & 265 \\
\hline
\end{tabular}

Fixed exchange rate regime

PANEL B: SNAKE COUNTRIES

\begin{tabular}{|c|c|c|c|c|c|c|}
\hline Currency & $\alpha_{1}$ & $\alpha_{2}$ & $\alpha_{3}$ & $\beta_{0}$ & $\beta_{1}$ & $\begin{array}{l}\text { No. of } \\
\text { Obs. }\end{array}$ \\
\hline Belgian frank & $\begin{array}{l}0.473 \\
(48.51)\end{array}$ & $\begin{array}{r}10.269 \\
(1142.43)\end{array}$ & $\begin{array}{r}54.327 \\
(6689.20)\end{array}$ & $\begin{array}{c}0.00070^{10} \\
(4.0 \mathrm{E}-4)\end{array}$ & $\begin{array}{r}19.7891 \\
(1.3 \mathrm{E}+1)\end{array}$ & 763 \\
\hline French frank & $\begin{array}{r}0.147 \\
(3.22)\end{array}$ & $\begin{array}{l}2.207 \\
(58.48)\end{array}$ & $\begin{array}{r}7.069 \\
(260.19)\end{array}$ & $\begin{array}{c}0.00040^{1} \\
(1.0 \mathrm{E}-4)\end{array}$ & $\begin{array}{l}0.2009 \\
(1.4 \mathrm{E}-1)\end{array}$ & 766 \\
\hline Netherland gulden & $\begin{array}{l}0.020 \\
(17.11)\end{array}$ & $\begin{array}{r}0.285 \\
(418.99)\end{array}$ & $\begin{array}{r}-0.710 \\
(2536.46)\end{array}$ & $\begin{array}{c}0.00013^{1} \\
(1.8 \mathrm{E}-5)\end{array}$ & $\begin{array}{r}-0.7770 \\
(5.6 \mathrm{E}-1)\end{array}$ & 640 \\
\hline Danish koruna & $\begin{array}{r}-0.036 \\
(0.53) \\
\end{array}$ & $\begin{array}{r}-0.669 \\
(6.58) \\
\end{array}$ & $\begin{array}{r}-2.775 \\
(18.31) \\
\end{array}$ & $\begin{array}{c}0.00070{ }^{1} \\
(1.2 \mathrm{E}-4)\end{array}$ & $\begin{array}{l}0.0824^{1} \\
(2.7 \mathrm{E}-2) \\
\end{array}$ & 610 \\
\hline \multicolumn{7}{|c|}{ Floating exchange rate regime } \\
\hline Belgian frank & $\begin{array}{r}-0.029 \\
(1.71)\end{array}$ & $\begin{array}{r}-1.666 \\
(66.06)\end{array}$ & $\begin{array}{r}-24.943 \\
(597.04)\end{array}$ & $\begin{array}{c}0.00008^{1} \\
(2.1 \mathrm{E}-5)\end{array}$ & $\begin{array}{l}5.7048{ }^{1} \\
(1.5 \mathrm{E}+0)\end{array}$ & 1298 \\
\hline French frank & $\begin{array}{r}-0.284 \\
(2.27)\end{array}$ & $\begin{array}{r}-11.800 \\
(90.43)\end{array}$ & $\begin{array}{r}-117.824 \\
(871.03)\end{array}$ & $\begin{array}{l}0.0003^{1} \\
(3.9 \mathrm{E}-5)\end{array}$ & $\begin{array}{l}2.7850^{1} \\
(4.0 \mathrm{E}-1)\end{array}$ & 1298 \\
\hline Netherland gulden & $\begin{array}{r}-0.034 \\
(1.71)\end{array}$ & $\begin{array}{r}-1.291 \\
(79.97)\end{array}$ & $\begin{array}{r}-11.570 \\
(868.98)\end{array}$ & $\begin{array}{c}0.00004^{1} \\
(4.5 \mathrm{E}-6)\end{array}$ & $\begin{array}{l}1.1479^{5} \\
(5.2 \mathrm{E}-1)\end{array}$ & 1298 \\
\hline Danish koruna & $\begin{array}{r}-0.144 \\
(0.96)\end{array}$ & $\begin{array}{r}-6.170 \\
(37.68)\end{array}$ & $\begin{array}{r}-63.434 \\
(352.46)\end{array}$ & $\begin{array}{c}0.00011^{1} \\
(4.2 \mathrm{E}-5)\end{array}$ & $\begin{array}{l}2.2814^{1} \\
(4.9 \mathrm{E}-1)\end{array}$ & 1298 \\
\hline
\end{tabular}

Fixed exchange rate regime 
Table 4.

Regression results of the following GARCH specification:

$$
\begin{aligned}
& r_{t}=a_{0}+\sum_{i=1}^{k} a_{i} r_{t-i}+\varepsilon_{t} ; \varepsilon_{t} \sim N\left(0, \sigma_{t}^{2}\right) \\
& \sigma_{t}^{2}=\omega+\alpha \varepsilon_{t-1}^{2}+\beta \sigma_{t-1}^{2}+\xi d_{t-1} \varepsilon_{t-1}^{2}
\end{aligned}
$$

\begin{tabular}{|c|c|c|c|c|c|c|c|c|}
\hline & \multicolumn{4}{|c|}{ Fixed exchange rate regime } & \multicolumn{4}{|c|}{ Floating exchange rate regime } \\
\hline & $\begin{array}{r}\text { Czech } \\
\text { koruna }\end{array}$ & $\begin{array}{l}\text { Slovak } \\
\text { koruna }\end{array}$ & Polish zloty & $\begin{array}{r}\text { Hungarian } \\
\text { forint } \\
\end{array}$ & $\begin{array}{r}\text { Czech } \\
\text { koruna }\end{array}$ & $\begin{array}{l}\text { Slovak } \\
\text { koruna }\end{array}$ & Polish zloty & $\begin{array}{r}\text { Hungarian } \\
\text { forint } \\
\end{array}$ \\
\hline$a_{0}$ & $\begin{array}{r}0.00001 \\
(0.0001) \\
\end{array}$ & $\begin{array}{r}0.00004 \\
(0.0001) \\
\end{array}$ & $\begin{array}{r}0.00008 \\
(0.0002)\end{array}$ & $\begin{array}{c}0.00017^{1} \\
(0.0000)\end{array}$ & $\begin{array}{c}-0.00022^{10} \\
(0.0001)\end{array}$ & $\begin{array}{r}0.00001 \\
(0.0001) \\
\end{array}$ & $\begin{array}{r}-0.00001 \\
(0.0004) \\
\end{array}$ & $\begin{array}{r}-0.00008 \\
(0.0002) \\
\end{array}$ \\
\hline$a_{1}$ & & & & $\begin{array}{r}-0.049 \\
(0.033)\end{array}$ & & & & $\begin{array}{r}-0.211 \\
(0.104)\end{array}$ \\
\hline$a_{2}$ & & & & $\begin{array}{r}-0.029 \\
(0.031)\end{array}$ & & & & $\begin{array}{r}-0.127 \\
(0.087)\end{array}$ \\
\hline$a_{3}$ & & & & $\begin{array}{r}-0.018 \\
(0.028)\end{array}$ & & & & $\begin{array}{r}-0.009 \\
(0.076)\end{array}$ \\
\hline$a_{4}$ & & & & $\begin{array}{r}-0.030 \\
(0.034)\end{array}$ & & & & $\begin{array}{l}-0.089^{10} \\
(0.075)\end{array}$ \\
\hline$a_{5}$ & & & & $\begin{array}{l}0.015 \\
(0.034)\end{array}$ & & & & $\begin{array}{r}-0.006 \\
(0.058)\end{array}$ \\
\hline$\varpi$ & $\begin{array}{c}7.28 \mathrm{E}-8^{5} \\
(3.1 \mathrm{E}-8)\end{array}$ & $\begin{array}{c}8.10 \mathrm{E}-7^{1} \\
(2.4 \mathrm{E}-7)\end{array}$ & $\begin{array}{c}5.66 \mathrm{E}-6^{1} \\
(6.7 \mathrm{E}-7)\end{array}$ & $\begin{array}{c}4.07 \mathrm{E}-9{ }^{1} \\
(1.1 \mathrm{E}-9)\end{array}$ & $\begin{array}{c}6.52 \mathrm{E}-7^{1} \\
(8.0 \mathrm{E}-8)\end{array}$ & $\begin{array}{c}4.95 \mathrm{E}-7^{1} \\
(9.4 \mathrm{E}-8)\end{array}$ & $\begin{array}{c}1.45 \mathrm{E}-5^{1} \\
(3.0 \mathrm{E}-6)\end{array}$ & $\begin{array}{c}6.40 \mathrm{E}-6^{1} \\
(2.0 \mathrm{E}-6)\end{array}$ \\
\hline$\alpha$ & $\begin{array}{l}0.067^{1} \\
(0.012)\end{array}$ & $\begin{array}{l}0.190^{1} \\
(0.028)\end{array}$ & $\begin{array}{l}0.311^{1} \\
(0.041)\end{array}$ & $\begin{array}{l}0.137^{1} \\
(0.014)\end{array}$ & $\begin{array}{l}0.075^{1} \\
(0.012)\end{array}$ & $\begin{array}{l}0.232^{1} \\
(0.023)\end{array}$ & $\begin{array}{l}0.193^{1} \\
(0.068)\end{array}$ & $\begin{array}{l}0.505^{1} \\
(0.105)\end{array}$ \\
\hline$\beta$ & $\begin{array}{l}0.937^{1} \\
(0.011)\end{array}$ & $\begin{array}{l}0.804^{1} \\
(0.039)\end{array}$ & $\begin{array}{l}0.709^{1} \\
(0.032)\end{array}$ & $\begin{array}{l}0.901^{1} \\
(0.004)\end{array}$ & $\begin{array}{l}0.866^{1} \\
(0.013)\end{array}$ & $\begin{array}{l}0.787^{1} \\
(0.016)\end{array}$ & $\begin{array}{l}0.672^{1} \\
(0.077)\end{array}$ & $\begin{array}{l}0.375^{1} \\
(0.107)\end{array}$ \\
\hline$\xi$ & $\begin{array}{c}-0.017^{10} \\
(0.010)\end{array}$ & $\begin{array}{c}-0.148^{1} \\
(0.028)\end{array}$ & $\begin{array}{c}-0.294^{1} \\
(0.042)\end{array}$ & $\begin{array}{c}-0.064^{1} \\
(0.019)\end{array}$ & $\begin{array}{l}0.076^{1} \\
(0.016)\end{array}$ & $\begin{array}{c}-0.106^{1} \\
(0.026)\end{array}$ & $\begin{array}{c}-0.226^{1} \\
(0.080)\end{array}$ & $\begin{array}{l}0.238^{1} \\
(0.240)\end{array}$ \\
\hline $\begin{array}{c}\text { Num. of } \\
\text { obs }\end{array}$ & 1048 & 684 & 864 & 1136 & 1232 & 904 & 535 & 268 \\
\hline
\end{tabular}

PANEL A: VISEGRAD COUNTRIES

PANEL B: SNAKE COUNTRIES

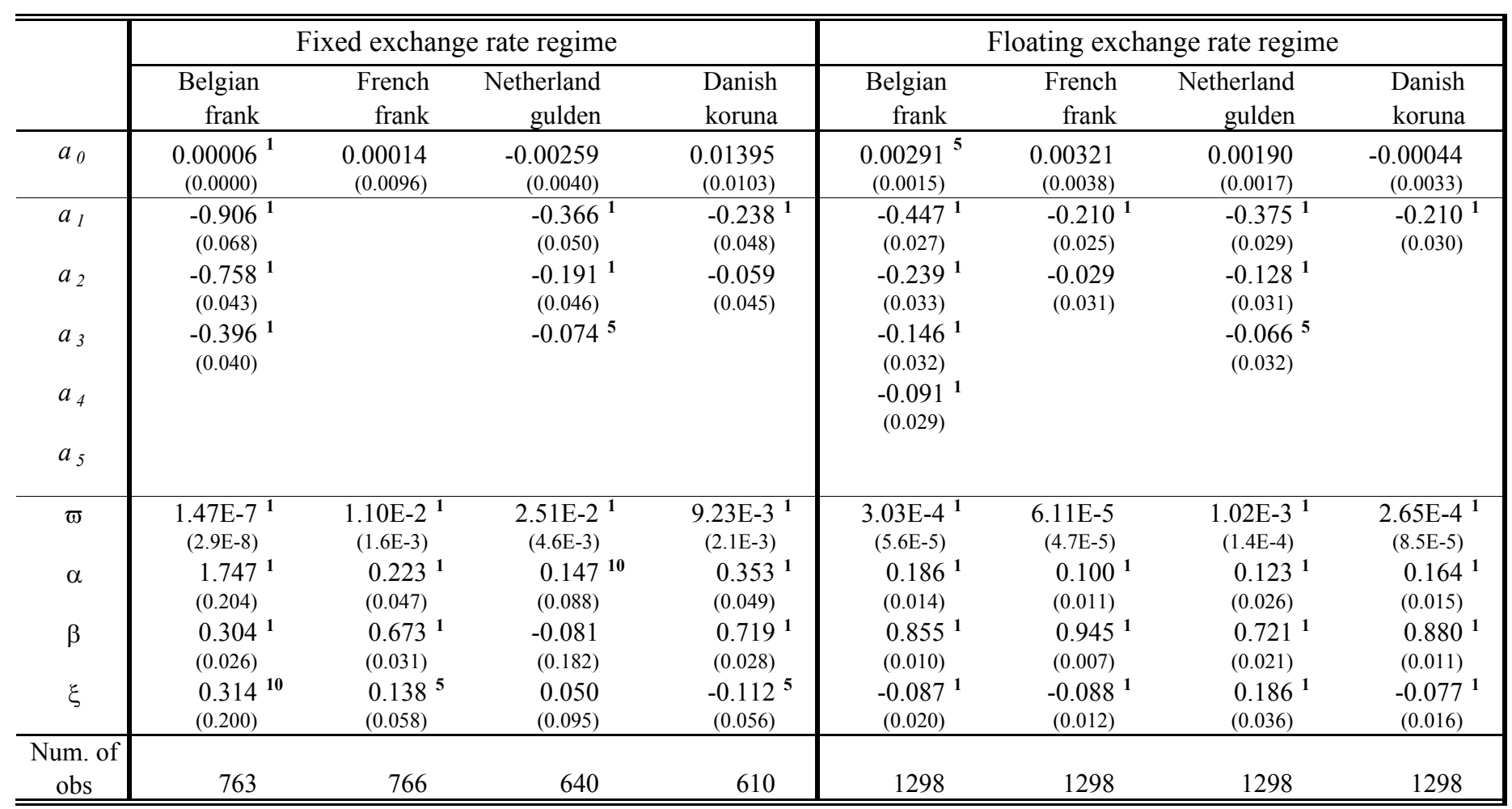


William Davidson Institute Working Paper 622

Figure 1

Times series of exchange rates of Visegrad countries
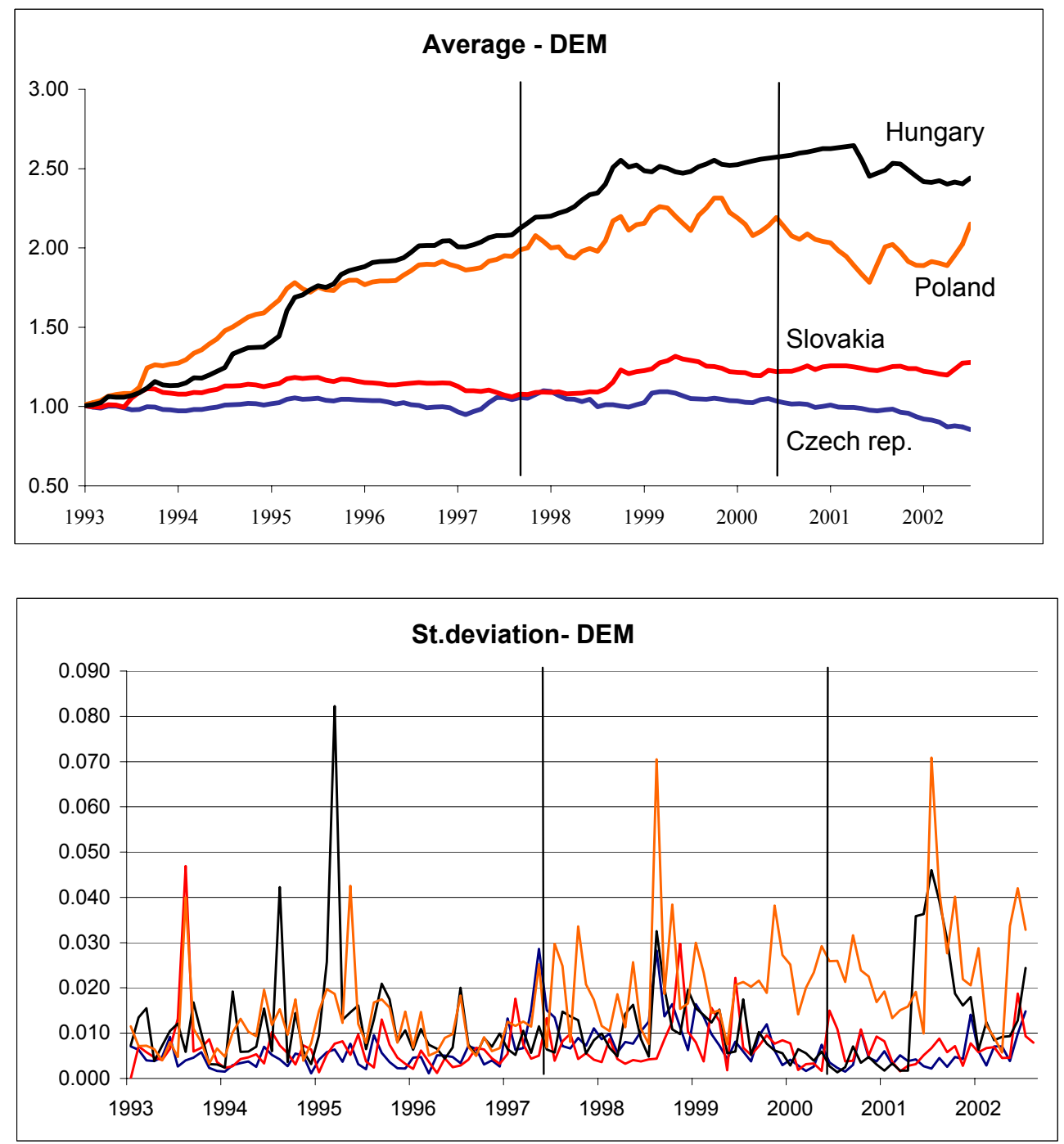
William Davidson Institute Working Paper 622

Figure 2

Times series of exchange rates for Snake countries
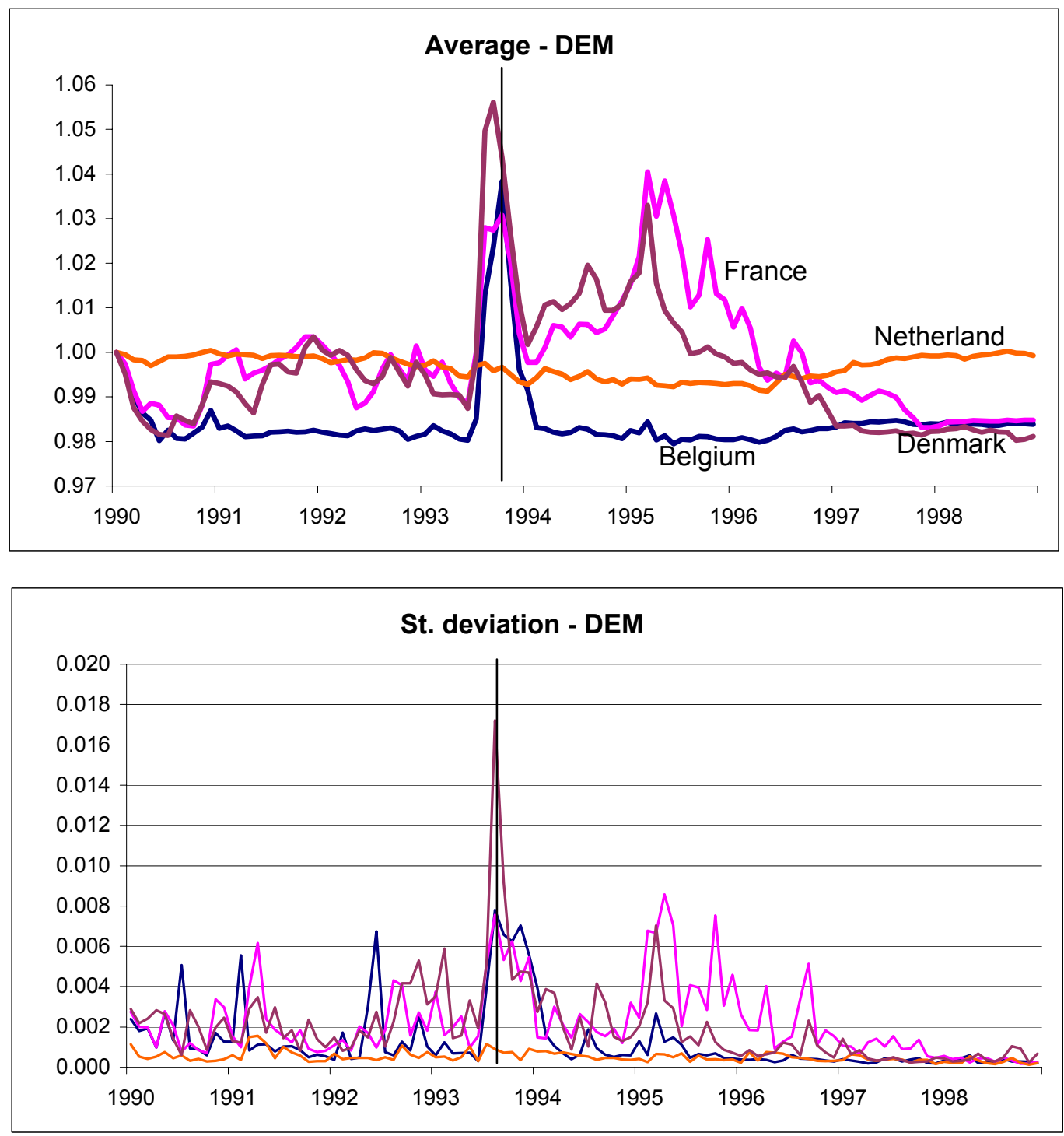


\section{References}

Ait-Sahalia, Yacine, 1996, "Testing continuous-time models of the spot interest rate", Review of Financial Studies 9, 385-426.

Andersen, Torben G., Bollerslev, Tim, Diebold, Francis X., and Paul Labys, 2001, "The distribution of realized exchange rate volatility", Journal of the American Statistical Association, 96 (453):42-55, March 2001.

Ayuso, J., Perez-Jurado, M. and F. Restoy, 1994, "Is exchange rate risk higher in the ERM after the widening of fluctuation bands?”, Documento de Trabajo 94149, Banco de Espana, Madrid.

Baillie RT, and Tim Bollerslev, 2000, "The forward premium anomaly is not as bad as you think", Journal of International Money and Finance 19: 471-478.

Bansal R. and M. Dahlquist, 2000, "The forward premium puzzle: different tales from developed and emerging economies", Journal of International Economics 51: (1) 115-144, June 2000.

Berndt, E. K., Hall, B. H., Hall, R. E. and J.A. Hausman, 1974, "Estimation of inference in nonlinear structural models", Annals of Economic and Social Measurement 4: 653665.

Bilson, John F.O., 1999, "The non-linear dynamics of exchange rates", Working Paper, Stuart Graduate School of Business, Illinois Institute of Technology.

Black, F., 1976, "Studies of stock market volatility changes", 1976 Proceedings of the American Statistical Association, Business and Economic Statistics Section, 177-181.

Bollerslev, Tim, 1986, "Generalized autoregressive conditional heteroscedasticity", Journal of Econometrics 31: 307-327.

Brasili A and B. Sitzia, 2003, "Risk related non linearities in exchange rates: Evidence from a panel of Central and Eastern European countries", Open Economies Review 14: (2) 135-155 April 2003.

Caporale, G.M., Hassapis, Ch. and N. Pittis, N, 1995, "Excess returns in the EMS - do weak currencies still exist after the widening of the fluctuation bands?", Weltwirtschaftliches Archiv-Review Of World Economics, 131 (2): 326-338.

Cox, John C., Jonathan E. Ingersoll, Jr., and Stephen A. Ross, 1985, “A theory of the term structure of interest-rates", Econometrica 53 (2), 385-407.

Elerian, Ola, Siddhartha Chib, and Neil Shephard, 2001, "Likelihood inference for discretely observed nonlinear diffusions", Econometrica 59 (4): 959-993, July 2001. 
Engle, R. F. and V. K. Ng, 1993, "Measuring and Testing the Impact of News on Volatility", Journal of Finance 48(5), 1749-78.

Fama E.F., 1984, "Forward and spot exchange-rates", Journal of Monetary Economics 14: (3) 319-338, November.

Flood Rober P. and Andrew K. Rose, 2002, "Uncovered interest parity in crisis", IMF staff papers 49: (2) 252-266.

Flood Rober P. and Andrew K. Rose, 1995, "Fixing exchange rates: A virtual quest for fundamentals", Journal of Monetary Economics 36:3-37.

Frankel, J.A. and K.A. Froot, 1987, "Using survey data to test standard propositions regarding exchange rate expectations", American Economic Review, 77 (1) 133-53, March.

Glosten, L., Jagannathan, R., and D. Runkle, 1993, "Relationship between the expected value and the volatility of the nominal excess returns on stocks", Federal Reserve Bank of Minneapolis Staff Report \# 157.

Hallett, A.H. and M.L. Anthony, 1997, "Exchange rate behavior under the EMS regime: Was there any systematic change?", Journal of International Money and Finance 16(4), August.

Halpern L. and C. Wyplosz, 1997, "Equilibrium exchange rates in transition economies", IMF Staff Papers 44 (4), 430-461.

Hamilton, J. D., and R. Susmel, 1994, “Autoregressive Conditional Heteroskedasticity and Changes in Regime“, Journal of Econometrics 64, 307-333.

Giavazzi, F. and A. Giovanninni, 1989, Limiting exchange rate flexibility, The MIT Press, Cambridge, Massachusetts.

Ivanicova, Z.and E. Rublikova, 2002, "Quantification of the development of Slovak crown after transition to floating rate", Ekonomicky Casopis, 50 (3), 359-372.

Keynes, J.M., 1923, A Track on Monetary Reform, London, Macmillan; reprinted as Vol. IV of the Collected Writings of J.M. Keynes, London, Macmillan for the Royal Economic Society, 1971.

Kirikos, Dimitris G., 2002, "Discrete policy interventions and rational forecast errors in foreign exchange markets: The uncovered interest parity hypothesis revisited", International Journal of Finance and Economics, 7: 327-338.

Kočenda, E., 2002, Exchange Rate Movements in European Transition Economies, In: Columbus, F. (ed.), European Economic and Political Issues V. Nova Science Publishers, New York. 
Kočenda, E., 2001, "Macroeconomic convergence in transition countries", Journal of Comparative Economics 29:1-23.

Kočenda, E., 1998, “Altered band and exchange rate volatility”, Economics of Transition, 6 (1):171-181.

Kočenda, E. and D. H. Papell, 1997, "Inflation convergence within the European Union: A panel data analysis", International Journal of Finance and Economics, 2(3):189-198.

Kmenta, Jan, Elements of Econometrics, Macmillan Publishing 2nd edition, 1990.

Krugman P.R., 1991, “Target zones and exchange-rate dynamics”, Quarterly Journal of Economics 106: (3) 669-682, August 1991.

Krugman, P.R., 1989, "The case for stabilizing exchange rates", Oxford Review of Economics, 106: 669-682.

Ledesma-Rodriguez F., Navarro-Ibanez, M., Perez-Rodriguez, J. and S. Sosvilla-Rivero, 2003, “Assessing the credibility of a target zone: A history of the EMS", Mimeo, presented at 81st conference of Applied Econometric Association on "Exchange Rates", Marseilles, France.

Nelson, D., 1991, "Conditional heteroskedasticity in asset returns: A New Approach", Econometrica 59, 347-370.

Papazoglou, C, 1999, "Exchange rate policy and output growth: The experience of the transition economies of Central and Eastern Europe", Post-Communist Economies 11 (3), 319-336, September 1999.

Robertson D. and J. Symons, 1992, "Output, inflation and the ERM", Oxford Economic Papers-New Series 44: (3) 373-386, July 1992.

Rose, A.K. and L.E.O. Svensson, 1994, "European exchange rate credibility before the fall", European Economic Review, 38:1185-1216.

Sapir A. and K. Sekkat, 1995, "Exchange-rate regimes and trade prices - Does the EMS matter", Journal of International Economics 38: (1-2) 75-94, February 1995.

Sosvilla-Rivero S., Fernandez-Rodriguez, Fernando, and Oscar Bajo-Rubio, 1999, "Exchange rate volatility in the EMS before and after the fall", Applied Economics Letters, 6:717-722.

Svensson, L.E.O., 1993, “Assessing target zone credibility: Mean reversion and devaluation expectations in the ERM, 1979-1992", European Economic Review, 37:763-802.

Szapary G. and ZM. Jakab, 1998, "Exchange rate policy in transition economies: The case of Hungary", Journal of Comparative Economics 26: (4), 691-717, December 1998. 


\section{William Davidson Institute Working Paper 622}

Tomczynska, M., 1998, "Exchange rate regimes in transition economies", CASE Studies \& Analyses Nr. 128.

Vasicek, Oldrich A., 1977, "An equilibrium characterization of the term structure", Journal of Financial Economics 5, 177-188.

Vinhas de Souza, L., 2002, "Integrated monetary and exchange rate frameworks: Are there empirical differences?", Working Paper Series, n² 2/2002, Bank of Estonia, Tallinn, Estonia. 


\section{DAVIDSON INSTITUTE WORKING PAPER SERIES - Most Recent Papers}

The entire Working Paper Series may be downloaded free of charge at: www.wdi.bus.umich.edu

CURRENT AS OF 10/16/03

\begin{tabular}{|c|c|c|}
\hline Publication & Authors & Date \\
\hline $\begin{array}{l}\text { No. 622: Exchange Rate Regimes and Volatility: Comparison of the } \\
\text { Snake and Visegrad }\end{array}$ & $\begin{array}{l}\text { Juraj Valachy and Evžen } \\
\text { Kočenda }\end{array}$ & Oct. 2003 \\
\hline $\begin{array}{l}\text { No. 621: Do Market Pressures Induce Economic Efficiency?: The Case } \\
\text { of Slovenian Manufacturing, 1994-2001 }\end{array}$ & $\begin{array}{l}\text { Peter F. Orazem and Milan } \\
\text { Vodopivec }\end{array}$ & Oct. 2003 \\
\hline $\begin{array}{l}\text { No. 620: Compensating Differentials in Emerging Labor and Housing } \\
\text { Markets: Estimates of Quality of Life in Russian Cities }\end{array}$ & $\begin{array}{l}\text { Mark C. Berger, Glenn C. } \\
\text { Blomquist and Klara Sabirianova } \\
\text { Peter }\end{array}$ & Oct. 2003 \\
\hline $\begin{array}{l}\text { No. 619: Are Foreign Banks Bad for Development Even If They Are } \\
\text { Efficient? Evidence from the Indian Banking Sector }\end{array}$ & $\begin{array}{l}\text { Sumon Bhaumik and Jenifer } \\
\text { Piesse }\end{array}$ & Oct. 2003 \\
\hline No. 618: The Echo of Job Displacement & $\begin{array}{l}\text { Marcus Eliason and Donald } \\
\text { Storrie }\end{array}$ & Oct. 2003 \\
\hline No. 617: Deposit Insurance During Accession EU Accession & $\begin{array}{l}\text { Nikolay Nenovsky and Kalina } \\
\text { Dimitrova }\end{array}$ & Oct. 2003 \\
\hline $\begin{array}{l}\text { No. 616: Skill-Biased Transition: The Role of Markets, Institutions, and } \\
\text { Technological Change }\end{array}$ & Klara Sabirianova Peter & Oct. 2003 \\
\hline $\begin{array}{l}\text { No. 615: Initial Conditions, Institutional Dynamics and Economic } \\
\text { Performance: Evidence from the American States }\end{array}$ & Daniel Berkowitz and Karen Clay & Sept. 2003 \\
\hline $\begin{array}{l}\text { No. 614: Labor Market Dynamics and Wage Losses of Displaced } \\
\text { Workers in France and the United States }\end{array}$ & Arnaud Lefranc & Sept. 2003 \\
\hline No. 613: Firm Size Distribution and EPL in Italy & $\begin{array}{l}\text { Fabiano Schivardi and Roberto } \\
\text { Torrini }\end{array}$ & Sept. 2003 \\
\hline $\begin{array}{l}\text { No. 612: The Effect of Employee Involvment on Firm Performance: } \\
\text { Evidence from an Econometric Case Study }\end{array}$ & Derek C. Jones and Takao Kato & Sept. 2003 \\
\hline No. 611: Working Inflow, Outflow, and Churning & $\begin{array}{l}\text { Pekka Ilmakunnas and Mika } \\
\text { Maliranta }\end{array}$ & Sept. 2003 \\
\hline $\begin{array}{l}\text { No. 610: Signaling in The Labor Market: New Evidence On Layoffs, } \\
\text { and Plant Closings }\end{array}$ & Nuria Rodriguez-Planas & Sept. 2003 \\
\hline $\begin{array}{l}\text { No. 609: Job Flows and Establishment Characteristics: Variations } \\
\text { Across U.S. Metropolitan Areas }\end{array}$ & R. Jason Faberman & Sept. 2003 \\
\hline No. 608: Dowry and Intrahousehold Bargaining: Evidence from China & Philip H. Brown & Sept. 2003 \\
\hline $\begin{array}{l}\text { No. 607: Policy Regime Change and Corporate Credit in Bulgaria: } \\
\text { Asymmetric Supply and Demand Responses }\end{array}$ & $\begin{array}{l}\text { Rumen Dobrinsky and Nikola } \\
\text { Markov }\end{array}$ & Sept. 2003 \\
\hline $\begin{array}{l}\text { No. 606: Corporate Performance and Market Structure During } \\
\text { Transition in Hungary }\end{array}$ & László Halpern and Gábor Kõrösi & Aug. 2003 \\
\hline $\begin{array}{l}\text { No. 605: Culture Rules: The Foundations of the Rule of Law and Other } \\
\text { Norms of Governance }\end{array}$ & $\begin{array}{l}\text { Amir N. Licht, Chanan } \\
\text { Goldschmidt, and Shalom H. } \\
\text { Schwartz }\end{array}$ & Aug. 2003 \\
\hline No. 604: Institutional Subversion: Evidence from Russian Regions & $\begin{array}{l}\text { Irina Slinko, Evgeny Yakovlev, } \\
\text { and Ekaterina Zhuravskaya }\end{array}$ & Aug. 2003 \\
\hline $\begin{array}{l}\text { No. 603: The Effects of Privitzation and International Competitive } \\
\text { Pressure on Firms' Price-Cost Margins: Micro Evidence from Emerging } \\
\text { Economics }\end{array}$ & $\begin{array}{l}\text { Jozef Konings, Patrick Van } \\
\text { Cayseele and Frederic Warzynski }\end{array}$ & Aug. 2003 \\
\hline No. 602: The Usefulness of Corruptible Elections & $\begin{array}{l}\text { Loren Brandt and Matthew } \\
\text { Turner }\end{array}$ & Aug. 2003 \\
\hline No. 601: Banking Reform In Russia: A Window of Opportunity & Abdur Chowdhury & Aug. 2003 \\
\hline $\begin{array}{l}\text { No. 600: The Impact of Structural Reforms on Employment Growth and } \\
\text { Labour Productivity: Evidence from Bulgaria and Romania }\end{array}$ & Ralitza Dimova & Aug. 2003 \\
\hline $\begin{array}{l}\text { No. 599: Does Product Differentiation Explain The Increase in Exports } \\
\text { of Transition Countries? }\end{array}$ & Yener Kandogan & July 2003 \\
\hline $\begin{array}{l}\text { No. 598: Organizational Culture and Effectiveness: } \\
\text { Can American Theory Be Applied in Russia? }\end{array}$ & $\begin{array}{l}\text { Carl F. Fey and Daniel R. } \\
\text { Denison }\end{array}$ & July 2003 \\
\hline
\end{tabular}

